\title{
SOCIAL ENTREPRENEURSHIP: PENERAPAN KEWIRAUSAHAAN PAULUS BAGI WIRAUSAHAWAN KRISTEN MASA KINI
}

\author{
David Eko Setiawan \\ Sekolah Tinggi Teologi Tawangmangu \\ davidekosetiawan14217@gmail.com
}

\begin{abstract}
This study aims to apply Paul's entrepreneurial characteristics as a form of Social Entrepreneurship for Christian entrepreneurs today. Researchers find that there is still little study of this matter so that more in-depth research is needed. In addition, the existing studies generally only examine the extent of entrepreneurship. In this study, the authors used the Reasech library method and the rhetorical criticism method to solve existing problems. The research problem that has been solved is how to apply Paul's entrepreneurial characteristics as a form of Social Entrepreneurship for Christian entrepreneurs today? The results of this study indicate that Christian entrepreneurs are basically social entrepreneurs who are required to be innovative, creative, smart in reading opportunities, helpful, and actively involved in social transformation such as Paul's entrepreneurial characteristics.
\end{abstract}

Keywords: Social Entrepreneurship, Paul Entrepreneurship, Christian Entrepreneur

Abstrak: Penelitian ini bertujuan untuk menerapkan karakteristik kewirausahaan Paulus sebagai wujud Social Enterpreneurship bagi wirausahawan Kristen masa kini. Peneliti mendapati bahwa kajian terhadap hal tersebut masih sedikit sehingga perlu dilakukan penelitian yang lebih mendalam. Di samping itu, kajian yang ada pada umumnya hanya mengkaji sebatas Enterpreneurship saja. Pada penelitian ini, penulis menggunakan metode library reasech dan metode kritik retorik untuk memencahkan masalah yang ada. Adapun problem research yang dipecahkan adalah bagaimanakah penerapan karakteristik kewirausahaan Paulus sebagai wujud Social Enterpreneurship bagi wirausahawan Kristen masa kini? Hasil dari penelitian ini menunjukkan bahwa wirausahawan Kristen pada dasarnya adalah Social Entrepreneur yang wajib memiliki inovasi, kreatif, cerdas membaca peluang, berjiwa penolong serta terlibat aktif dalam transformasi sosial seperti krakteristik kewirausahaan Paulus.

Kata kunci: Social Entrepreneurship, Kewirausahaan Paulus, Wirausahawan Kristen

Isu seputar enterpreneurship sempat menjadi pro dan kontra di

dalam gereja. Mereka yang tidak setuju berpandangan bahwa gereja seharusnya tidak boleh mencampuradukkan dunia bisnis dengan pelayanan gerejawi (Julianto, 2016). Pandangan ini didasarkan atas kisah dalam Matius 21:12, pengusiran pedagang yang berjualan di halaman Bait Suci oleh Tuhan Yesus (Mat 21:12). Sedangkan bagi yang setuju David Eko Setiawan 
berpendapat bahwa di dalam kisah tersebut Yesus bukannya tidak setuju dengan bisnis di halaman Bait Suci, namun Dia sedang menentang keserakahan dan kecurangan kaum Sanhedrin yang mencari keutungan kotor melalui penarikan pajak dari para pedagang dengan mempekerjakan pemungut cukai (Julianto, 2016). Pemicu lain adalah munculnya pandangan dualistis di dalam gereja yang memandang bahwa pekerjaan yang berkaitan dengan keagamaan lebih rohani dibandingkan dengan pekerjaan duniawi (Silalahi, 2019). Semuanya itu telah memunculkan sikap pro dan kontra dan juga percakapan berkepanjangan seputar enterpreneurship di dalam gereja. Padahal jika dikaji lebih mendalam ternyata enterpreneurship dapat menjadi salah satu bentuk pelayanan diakonia gerejawi bagi masyarakat majemuk. Melalui Social Enterpreneurship (SE), gereja dapat membangun "jembatan" dengan masyarakat yang termarginalkan tanpa dibatasi oleh sekat-sekat politik yang ada (E. S. Saragih, 2019).

Social Enterpreneurship (SE) merupakan praktek kewirausahaan yang menarik untuk dikaji karena memiliki potensi untuk memecahkan berbagai masalah sosial yang ada di tengah-tengah masyarakat. Menurut Manyaka, aspek positif dari SE adalah selain mendapatkan penghasilan untuk mempertahan proyeknya, wirausahawan sosial juga dapat memberikan solusi bagi masalah-masalah sosial (Manyaka, 2015). Dalam penelitiannya di Nellmapius, Afrika Selatan, Manyaka menemukan bahwa melalui SE, para wirausahawan sosial memainkan peran penting sebagai 
agen perubahan di berbagai sektor sosial di kawasan termiskin tersebut (Manyaka, 2015). Selanjutnya, penelitan Saragih dan Elisabeth menemukan bahwa SE telah memberikan kontribusi positif dalam menyelesaikan masalah sosial di tengah masyarakat akibat pandemi Covid-19 dengan memberikan nilai tambah serta pemberdayaan potensi mereka yang terdampak pandemi (R. Saragih \& Elisabeth, 2020).

Meskipun SE telah begitu jelas memberikan dampak sosial bagi masyarakat, namun kajian terhadap isu ini di dalam gereja rupanya masih sedikit. Memang telah ada beberapa penelitian yang mengkaji isu-isu enterpreneurship, semisal penelitian Pasande dan Tari yang menyoroti peran gereja dalam pengembangan kewirausahaan di era digital (Pasande \& Tari, 2019). Dalam penelitiannya tersebut, penulis menemukan bahwa dengan berkembangnya teknologi yang begitu pesat maka gereja seyogyanya menanggapi perubahan itu dan juga harus berperan dalam kewirausahaan secara on line. Penelitian lainnya adalah tentang kewirausahaan jemaat sebagai sebuah alternatif berteologi yang dilakukan oleh Julianto (Julianto, 2016). Peneliti menemukan bahwa refleksi teologis terhadap praktek kewirausahaan di tengah-tengah jemaat dapat menjadi menolong jemaat untuk menelusuri karya penciptaan, karya Yesus Kristus dan karya Paulus dengan kaca mata yang berbeda sehingga dapat mendorong mereka memahami dasar-dasar teologis tentang kewirausahaan. Lalu, Tafonao dalam penelitiannya tentang pendidikan kewirausahaan bagi warga gereja di era digital menunjukkan 
bahwa gereja harus terlibat dalam banyak sisi kehidupan jemaat, baik sosial, ekonomi dan lain-lain, khususnya dalam peningkatan ekonomi jemaat melalui pendidikan kewirausahaan di era digital masa kini (Tafonao, 2020). Selanjutnya, Adi dalam penelitiannya tentang kewirausahaan dan panggilan Kristen menemukan bahwa berdasarkan pendekatan interpretative-dialogis, sosiologis-historis dan teologis, kewirausahaan bisa dijadikan dasar panggilan Kristen untuk menciptakan kesejahteraan dan keadilan masyarakat (Adi, 2020). Terakhir, terdapat dua penelitian yang lebih relevan dengan penelitian yang dilakukan oleh peneliti saat ini yaitu pertama, penelitian Silalahi tentang Paulus sang entrepreneur, dimana dalam penelitiannya ditemukan prinsip-prinsip kewirausahaan Paulus yang relevan bagi pelayanan hamba Tuhan masa kini (Silalahi, 2019). Kedua, penelitian Saragih tentang fungsi gereja sebagai entrepreneurship sosial dalam masyarakat majemuk, dimana peneliti menemukan bahwa entrepreneurship sosial dapat menjadi solusi sebagai diakonia sosial yang bebas dari stigmatisasisi Kristenisasi dan juga dapat menyelesaiakan masalah-masalah sosial dalam gereja dan masyarakat (E. S. Saragih, 2019).

Jika dibandingkan dengan beberapa penelitian di atas, maka penelitian ini memiliki perbedaan yang signifikan yaitu terfokus pada Social Enterpreneurship. Sedangkan problem reseach yang perlu dijawab dalam penelitian ini adalah bagaimanakah penerapan Social Enterpreneurship bagi wirausahawan Kristen masa kini berdasarkan 
karakteristik kewirausahaan Paulus? Sedangkan tujuan dari penelitian ini adalah menemukan penerapan Social Enterpreneurship bagi wirausahawan Kristen masa kini berdasarkan karakteristik kewirausahaan Paulus.

\section{METODE}

Metode yang digunakan dalam penelitian adalah studi pustaka. Melalui metode tersebut peneliti berusaha memperoleh data-data penelitan dengan menelusuri sumber-sumber kepustakaan seperti bukubuku, artikel-artikel dan jurnal-jurnal penelitian (Trygu, 2020). Sedangkan analisis yang dipakai dalam metode ini adalah content analysis yang merupakan suatu teknik analisis untuk membuat suatu kesimpulan dari berbagai dokumen tertulis atau rekaman, dengan cara mengidentifikasi secara sistematis dan obyektif suatu pesan atau data dalam konteksnya yang selanjutnya diberi makna untuk memperoleh jawaban atas masalah penelitian yang mempertimbangkan (Yusuf, 2019).

Selain itu, peneliti juga menggunakan metode kritik retorik yang berupaya memahami teks dengan tidak mempertimbangkan unsur-unsur eksternal dari teks tetapi berupaya dengan cermat memperhatikan dan memahami teks, konteks, retor dan audien berdasarkan petunjuk-petunjuk internal agar mendapatkan makna yang berarti (Leeman, 2017) 


\section{HASIL}

Dengan mempertimbangkan berbagai temuan dalam penelitian ini, maka didapat hasil sebagai berikut: Pertama, Paulus adalah seorang Social Entrepreneur yang memiliki karakteristik inovatif, kreatif dan mampu membaca peluang dengan baik (Kis. 18:3; 20:34; II Tes. 3: 7-9), seorang yang mandiri namun mudah bekerjasama dengan pihak lain (Kis. 18:3; Kis. 20:34), bekerja bukan untuk dirinya sendiri namun hasilnya juga untuk orang lain (Kis. 20:34-25), dan dia juga aktif terlibat dalam transformasi sosial dalam masayarakat (I Tes. 2: 1-12). Kedua, Social Entrepreneur Kristen dapat menerapkan karakteristik kewirausahaan Paulus dalam wujud Social Entrepreneurship di tengah masyarakat. Dengan menerapkannya, maka Social Entrepreneur Kristen telah terlibat aktif dalam menyelesaikan masalah-masalah sosial. Ketiga, Social Entrepreneurship merupakan bidang yang patut diperhatikan oleh gereja masa kini. Mengingat bidang ini juga merupakan panggilan Kristen yang di dalamnya pelayanan diakonia gereja dapat lebih kontekstual dan dapat dimaksimalkan. Bahkan melaluinya warga jemaat dapat mempraktekkan Teologi Kewirausahaan di mana rekam jejaknya terdapat dalam Alkitab. Terlebih dari itu melalui Social Entrepreneurship, wirausahawan Kristen dapat mewujudkan panggilannya sebagai garam dan terang dunia. Keterlibatan mereka melalui Social Entrepreneurship akan menghasilkan perbuatan baik yang dapat dilihat oleh semua orang (Matius 15:6). 


\section{PEMBAHASAN}

\section{Hakikat Wirausahawan dan Enterpreneurship}

Entrepreneur adalah istilah yang sangat popular pada masa kini. Selain popular, istilah tersebut juga menjadi topik yang sedang ramai diperbincangkan dan menarik untuk dikaji. Apakah sejatinya makna dari istilah entrepreneur itu? Pada bagain ini penulis akan menjelaskan pengertian istilah tersebut.

Filion menjelaskan bahwa istilah entrepreneur merupakan turunan dari kata dalam bahasa Prancis yaitu entreprendre yang berarti melakukan dan mengusahakan (Filion, 2011). Selanjutnya, kata tersebut dapat dibagi menjadi dua bagian yaitu entre yang berarti "antara" dan prendre yang berarti "mengambil", sehingga kata ini sering digunakan untuk orangorang yang berani mengambil resiko dan memulai sesuatu yang baru (Zamzami, 2019). Sedangkan Julianto mendefinisikan wirausahawan/ entrepreneur sebagai "seseorang yang mempunyai cara berpikir yang berbeda dari manusia pada umumnya, dan di dalam dirinya terdapat motivasi, panggilan jiwa, persepsi, dan emosi yang sangat terkait dengan nilai-nilai, sikap dan prilaku sebagai manusia kerja" (Julianto, 2016). Jadi pada hakikatnya wirausahawan/entrepeneur adalah orang yang memiliki seperangkat karakteristik yang berbeda dengan manusia lainnya, dimana dia mampu mencipta, merancang, merencanakan, menjadi perantara, dan melayani berdasarkan nilai-nilai, sikap dan prilaku manusia kerja. 
Entrepreneurship merupakan suatu inovasi serta kreatifitas untuk menggunakan kesempatan dalam melahirkan perubahan yang menimbulkan nilai positif bagi dirinya sendiri dan lingkungannya (Margahana, 2020). Julianto mengutip Lestari mendefinisikan entrepreneurship sebagai "proses mengidentifikasi, mengembangkan, dan membawa visi ke dalam kehidupan dalam bentuk ide inovatif, peluang, cara yang lebih baik dalam menjalankan sesuatu, yang hasil akhir adalah penciptaan usaha baru yang dibentuk pada kondisi resiko" (Julianto, 2016). Selain sebagai proses, entrepreneurship juga didefinisikan sebagai membangun pola pikir dan ketrampilan yang tujuan akhirnya adalah menghasilkan peluang kerja dan pembangunan ekonomi (Diandra \& Azmy, 2020).

\section{Konsep Social Entrepreneurship}

Social Entrepreneurship merupakan salah satu istilah dalam kewirausahaan yang di dalamnya memiliki konsep yang beragam. Menurut Sofia, Social Entrepreneurship mengandung dua hal kunci yaitu pertama, inovasi sosial yang mampu mentransformasi sistem yang ada di dalam masyarakat. Kedua, hadirnya individu bervisi, kreatif, berjiwa wirausaha dan beretika di belakang gagasan inovatif tersebut (Sofia, 2017). Selanjutnya, Social Entrepreneurship sebenarnya mengacu kepada aktivitas individu atau kelompok yang mampu mengidentifikasi kesenjangan sosial sebagai kesempatan untuk menolong masyarakat $\frac{\text { yang termaginalkan dengan memenuhi kebutuhan mereka melalui jalur }}{\text { David Eko Setiawan }}$ 
kewirausahaan (Canestrino et al., 2020). Pada dasarnya, Social Entrepreneurship tidak sekedar berorientasi pada keuntungan bagi sang wirausahawan namun juga bertujuan untuk membagikan nilai kepada masyarakat yang kurang terlayani, terabaikan dan terpinggirkan (Manyaka, 2015). Dengan demikian Social Entrepreneurship bukan sekedar usaha yang mampu mengelola sumber-sumber daya yang dimiliki secara ekonomis dan tingkat produktivitas yang rendah menjadi tinggi, namun di dalamnya juga terdapat motif dan prilaku dari wirausahawan untuk memikirkan keuntungan bagi transformasi masyarakat yang termarginalkan. Sebab itu wirausahawan sosial akan mengejar nilai yang lebih tinggi yaitu perubahan sosial di dalam masyarakat, dibandingkan sekedar keuntungan pribadi (Lubberink et al., 2019). Terdapat beberapa elemen sosial yang menjadi pembentuk definisi Social Entrepreneurship, antara lain: Pertama, mengacu kepada sebuah aktivitivitas yang diinisiasi dan dilakukan oleh warga. Kedua, tingkat pengambilan keputusan yang tidak didasarkan pada kepemilikian modal. Ketiga, tujuan dan targetnya jelas yaitu menjadi bermanfaat bagi masyarakat. Dari berbagai penjelasan di atas tergambar bahwa Social Entrepreneurship "merupakan gerakan dengan misi sosial yang diusahakan dengan upaya-upaya menemukan peluang dan mengolahnya melalui proses belajar yang tiada henti serta kesiapan untuk bertindak tanpa dukungan sumber daya yang memadai" (Wibowo \& Nulhaqim, 2015). 
Menurut Al-Khafi, seorang Social Entrepreneurship wajib memperhatikan beberapa hal dalam memulai proyeknya yaitu (Al-Kahfi, 2020): Pertama, dia harus menyadari bahwa kemiskinan menjadi problem sosial yang harus dicarikan solusi. Kedua, mulai merancangkan gerakan inovatif melalui sosial enterprise yang diharapkan dapat menjadi solusi bagi masalah sosial. Ketiga, mulai menetapkan orientasi yang berbasis kepada manfaat sosial dan bukan sekedar keuntungan financial saja. Keempat, menindak lanjuti bentuk usaha yang ada dengan memberikan proteksi.

\section{Ciri-ciri Social Entrepreneur/Wirausahawan Sosial}

Terdapat perbedaan yang signifikan antara wirausahawan dengan Social Entrepreneur. Perbedaan tersebut dapat dilihat dari beberapa ciri berikut. Wirausahawan adalah seseorang yang kreatif menciptakan perubahan dengan memanfaatkan peluang dan sumber-sumber yang ada untuk menghasilkan keutungan bagi dirinya sendiri dan orang lain (Silalahi, 2019). Sedangan wirausahawan sosial/social entrepreneur adalah pengusaha sosial yang berusaha menciptakan dan mewujudkan nilai-nilai sosial di tengah-tengah masyarakat sehingga terwujud perubahan sosial yang berguna bagi pengembangan masyarakat ( $R$. Saragih \& Elisabeth, 2020). Berbeda dengan wirausahawan tradisional yang selalu mengejar keuntungan materi dan kepuasan pelanggan, social entrepreneur akan berusaha menemukan masalah yang sedang terjadi di

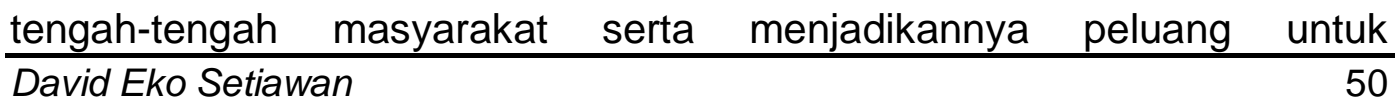


membentuk sebuah model bisnis baru yang bermanfaat bagi masyarakat sektarnya (Utomo, 2014).

Sebagai contoh, ketika Muhammad Yunus, seorang ekonom dan profesor ekonomi dari Bangladesh dan pendiri Grameen Bank melihat bahwa sebenarnya orang-orang miskin memiliki kemampuan dalam mengembangkan usaha namun sayangnya tidak memiliki peluang dukungan dari lembaga keuangan karena tidak memenuhi syarat sebagai nasabah, maka dia berusaha mengatasi masalah itu dengan mendirikan bank yang dapat memberikan kredit tanpa jaminan kepada warga miskin pedesaan (Kickul et al., 2012). Kredit diprioritaskan kepada penduduk desa termiskin dan tidak memiliki tanah, serta kepada perempuan yang miskin secara ekonomi dan sosial (Kickul et al., 2012). Inovasi Muhammad Yunus ini telah memberikan keuntungan transformatif bagi masyarakat yang termarginalkan dan juga Bank Grameen, selain itu membuatnya juga meraih penghargaan hadiah Nobel Perdamaian pada tahun 2006 (Utomo, 2014).

Terkait dengan penjelasan di atas maka perlu diringkaskan ciri-ciri Wirausahawan Sosial. Ciri-cirinya adalah sebagai berikut: Pertama, memiliki misi sosial dan bukan sekedar mencari profit pribadi (Bikse et al., 2015). Kedua, inovatif, kreatif serta berinisiatif dalam menciptakan nilai sosial yang transformatif bagi masyarakat (Mursalim \& Kurniati, 2020). Ketiga, mampu bekerjasama dengan pihak lain dalam membentuk partisipasi masyarakat sipil dengan mengoptimalkan modal sosial yang David Eko Setiawan 
ada (Utomo, 2014). Keempat, mengukur keberhasilan bukan dari profit materi namun melalui tercapainya tujuan sosial dengan memberikan solusi konkrit bagi masyarakat (Bikse et al., 2015). Kelima, mampu membaca peluang di tengah problematika masyarakat yang termarginalkan, memiliki kompetensi sosial serta toleran kepada siapapun (Bikse et al., 2015).

Selanjutnya, wirausahawan sosial akan membangun bisnis sosialnya dengan melibatkan empat elemen penting yaitu (AI-Kahfi, 2020): Pertama, social value. Elemen ini akan mendorong wirausahawan sosial untuk menciptakan manfaat sosial bagi masyarakat sekitarnya. Kedua, civil society. Wirausahawan sosial akan berkolaborasi dengan pihak lain dalam menggerakkan partisipasi masyarakat sipil dalam transformasi sosial melalui kegiatan ekonomi. Ketiga, innovation. Masalah yang muncul di dalam masyarakat akan direspon oleh wirausahawan sosial serta dicarikan melalui kearifan lokal dan inovasi sosial. Keempat, economy activity. Wirausahawan sosial mengembangkan aktivis ekonomi menjadi misi sosial yang trasformatif bagi masyarakat.

\section{Gereja dan Social Entrepreneurship}

Pembahasan seputar entrepreneurship di dalam gereja sempat menjadi pro dan kontra. Julianto menjelaskan bahwa isu boleh tidaknya gereja berwirausaha telah menjadi topik percakapan yang hangat (Julianto, 2016). Dia menjelaskan bahwa kelompok yang tidak setuju \begin{tabular}{lrrrr} 
bisanya berargumen & bahwa dunia & kewirausahaan & tidak & boleh \\
\hline David Eko Setiawan & & & 52
\end{tabular} 
dicampuradukkan dengan pelayanan gerejawi, karena terdapat contoh dalam Injil Matius 21:12 dan Lukas 19:45. Bagi kelompok yang setuju berpendapat bahwa teks tersebut tidak dapat dijadikan landasan penolakan entrepreneurship di dalam gereja. Ayat-ayat tersebut sebenarnya merupakan contoh penolakan Yesus terhadap praktek kecurangan Sanhendrin yang mengeruk keuntungan dengan penarikan pajak dan memperkerjakan para pemungut cukai di Bait Allah dan bukan kepada praktek kewirausahaan (Julianto, 2016). Hal senada diamati juga oleh Silalahi, di mana pro dan kontra terhadap kajian tentang entrepreneurship pernah muncul di dalam gereja bebera waktu ini (Silalahi, 2019). Adapun salah satu pemicunya adalah adanya pandangan dualistis yang mempertentangkan antara pekerjaan rohani dan duniawi. Sabdono seperti yang dikutip Silalahi menyatakan bahwa profesi yang berkaitan dengan kegiatan agamawi dianggap sebagai pekerjaan rohani, sedangkan yang di luar itu adalah duniawi (Silalahi, 2019). Pandangan dualistis tersebut mempertajam pro dan kontra terhadap pembahasan seputar entrepreneurship di dalam gereja.

Meskipun isu entrepreneurship di dalam gereja masih menjadi pro dan kontra, namun realita yang tidak dapat ditolak adalah ada sebagian warga jemaat yang menjadi wirausahawan, bahkan terdapat juga beberapa aliran gereja yang mengijinkan hamba Tuhan penuh waktu untuk berbisnis (Palabirin \& Ronda, 2010). Bagaimanakah sebenarnya relasi antara gereja dan entrepreneurship ini? Beberapa penelitian telah 
menunjukkan relasi tersebut, semisal Adi dalam kesimpulan penelitiannya menunjukkan bahwa entrepreneurship selayaknya dipertimbangkan sebagai panggilan Kristen bila itu dilakukan dengan dasar intellectus yang berpusat pada Tuhan, yang dijalankan dalam opera yang berdasarkan good governance, yang menghasilkan keadilan dan kebaikan bersama (Adi, 2020). Peneliti lainnya adalah Julianto yang menyimpulkan bahwa pengalaman entrepreneurship pada jemaat dapat dijadikan landasan praksis berteologi kewirausahaan sehingga hal tersebut bukan lagi menjadi hal tabu di kalangan Kristen (Julianto, 2016). Selanjutnya, Kusni melihat adanya relasi antara entrepreneurship dengan pemimpin dalam penatalayanan gereja, di mana pemimpin gereja yang memiliki jiwa entrepreneurship akan maksimal dalam melaksanakan pelayanan diakonianya (Kusni, 2020). Jika diamati hasil beberapa penelitian di atas maka jelaslah relasi antara gereja dengan entrepreneurship saling terkait, bahkan memberikan benefit bagi warga jemaat dan gereja sebagai institusi.

Lalu bagaimanakah relasinya dengan Social Entrepreneurship? Saragih menjelaskan bahwa melalui Social Entrepreneurship gereja dapat berfungsi maksimal melalui pelayanan diakonianya, karena dengan hal itu gereja dapat terlibat langsung dalam transformasi sosial dan terhindar dari stigmai Kristenisasi (E. S. Saragih, 2019). Dalam konteks ini dibutuhkan peran wirausahawan Kristen dalam mengembangkan social entrepreneurship di tengah-tengah masyarakat majemuk. Keterlibatan 
aktif mereka itu merupakan perwujudan identitas garam dan terang bagi dunia (Matius 5:13-16). Wirausahawan Kristen perlu menyatakan perbuatan baik mereka di depan banyak orang (Matius 5:16) melalui kompetensi kewirausahaannya. Social entrepreneurship dapat menjadi wadah bagi pengabdian wirausahawan Kristen kepada sesama. Sebab itu, gereja perlu mempersiapkan diri dengan mendidik para wirausahawan Kristen agar memiliki ide yang kreatif dan inovatif (Tafonao, 2020).

\section{Mengenal Kewirausahaan Paulus}

Rasul Paulus adalah salah satu tokoh besar di Alkitab yang memiliki pengaruh dalam penyebarlauasan Injil ke seluruh bumi. Dia adalah seorang Yahudi dengan nama Ibrani Sa'ul dan nama Romawi Paulos, telah mengalami pertobatan yang luar biasa (Kis. 9:3; 22:6; 26:13) bahkan kemudian menjadi rasul Kristus bagi bangsa-bangsa non Yahudi (Roma 11:13) serta dipakai oleh Allah menjadi misionari dan teolog yang handal (Setiawan \& Yulianingsih, 2019). Di samping itu dia adalah seorang entrepreneur (Kis. 18:3) yang berwirausaha sebagai tukang kemah (Silalahi, 2019). Setelah dia meninggalkan kota Atena, Paulus pergi ke kota Korintus, sebuah kota kosmopolitan dengan perdagangannya yang ramai (Silalahi, 2019) untuk melanjutkan misi pemberitaan Injil (Kis. 18:4). Di kota tersebut dia bertemu Akwila dan Priskila, serta singgah di rumahnya. Rupanya pasangan suami istri tersebut memiliki keahlian yang sama dengan Paulus sebagai pembuat dan pedagang kemah, kemudian mereka bekerja bersama-sama (Kis. David Eko Setiawan 
18:2). Di samping itu, Paulus juga aktif memberitakan Injil kepada orangorang Yahudi dan orang-orang Yunani di Korintus (Kis. 18:3) Menurut Adi, apa yang terjadi ini menunjukkan bahwa aktivitas pemberitaan Injil Paulus tidak terpisahkan dari pekerjaannya sebagai pembuat dan pedagang kemah (Adi, 2020). Selanjutnya dia menjelaskan bahwa sembari membuka usahanya dan melayani para pembeli, Paulus memberitakan Injil kepada semua orang melalui percakapan yang intensif (Adi, 2020). Pola tersebut rupanya juga dipakai oleh Paulus di beberapa tempat yang lain, semisal di Efesus (Kis. 20:34); dan kemungkinan di Tesalonika juga ( II Tesalonika 3:8-9).

Berkaitan dengan penjelasan di atas, maka penulis berusaha untuk menemukan karekteristik Paulus dan kewirausahaannya berdasarkan laporan Lukas dalam Kitab Kisah Para Rasul dan korespondensinya dengan jemaat melalui surat-suratnya. Beberapa prinsip yang dapat ditarik dari kewirausahaan Paulus adalah sebagai berikut:

Pertama, Paulus adalah entrepreneur yang dapat inovatif, kreatif dan mampu membaca peluang dengan baik. Hal ini dibuktikan dari bentuk wirausaha yang dia pilih yaitu pembuat dan pedangan kemah (Kis. 18:3; 20:34; II Tes. 3: 7-9). Berkaitan dengan wirausaha Paulus sebagai pembuat kemah, Szesnat menjelaskan bahwa Paulus terlibat dalam produksi pembuatan tenda dari bahan kulit, linen, dan silicum di mana bahan-bahan tersebut terkait dengan area dimana dia berada (Szesnat, 1993). Rupanya melalui beraneka ragam bahan tersebut, Paulus 
berusaha menyesuaikan produknya dengan permintaan para pelanggannya serta mempertimbangkan ketersediaan bahan yang ada di tempat-tempat dia singgah (Szesnat, 1993). Menurut Szesnat, tenda yang dibuat oleh Paulus bukanlah barang mewah, namun dibutuhkan oleh orang-orang di tempat di berada (Szesnat, 1993). Paulus seorang entrepreneur yang inovatif dan kreatif ditandai dapat memproduksi tenda dari berbagai bahan sesuai dengan pesanan pelanggannya. Dia juga mampu membaca peluang pasar, di mana hasil produksinya bukanlah barang mewah serta dibutuhkan oleh setiap orang.

Kedua, Paulus adalah seorang yang mandiri namun mudah bekerjasama dengan pihak lain. Ini dibuktikan saat Paulus singgah di rumah Priskila dan Akwila, mereka langsung dapat bekerja sama dalam pekerjaan (Kis. 18:3). Kata "mereka" pada ayat 3 memberikan petunjuk bahwa Paulus, Akwila dan Priskila terlibat bersama dalam bisnis pembuatan tenda tersebut (Silalahi, 2019). Disamping itu, Paulus adalah seorang yang mandiri, mampu self-support melalui pekerjaannya. Hal ini tampak dalam pidato perpisahannya dengan para penatua jemaat di Efesus, di situ Paulus menjelaskan bahwa dengan tangannya sendiri dia telah bekerja untuk mencukupi kebetuhannya sendiri (Kis. 20:34).

Ketiga, Paulus adalah seorang social entrepreneur yang bekerja bukan untuk dirinya sendiri namun hasilnya juga untuk orang lain (Kis. 20:34-25). Rupanya hasil bisnis membuat tenda yang dikerjakan oleh Paulus tidak untuk dirinya sendiri, namun juga untuk keperluan rekan- 
rekan seperjalanannya. Paulus bukan sekedar mengejar keutungan materi saja, namun juga memiliki kepedulian terhadap keperluan orang lain. Berdasarkan contoh itulah, dia menasehati para penatua Efesus untuk membantu oran-orang yang lemah. Hal ini juga yang melatarbelakangi nasehatnya kepada jemaat di Efesus untuk bertobat dari mencuri dan kemudian mulai bekerja supaya dengan pekerjaannya yang baik itu dia dapat membagikan sesuatu kepada orang yang berkekurangan (Ef. 4:28).

Keempat, Paulus adalah seorang social entrepreneur yang aktif terlibat dalam transformasi sosial dalam masayarakat (I Tes. 2: 1-12). Dalam suratnya yang pertama kepada jemaat di Tesalonika tampak bagaimana perjuangan Paulus dan rekan-rekannya dalam pemberitaan Injil di sana. Pada ayat 2, dia menyebut usaha pemberitaan Injil di Tesalonika adalah "perjuangan yang berat". Selain itu untuk menjaga kemurnian Injil dari motif palsu, Paulus tidak segan-segan untuk bekerja siang dan malam untuk mencukupi kebutuhannya selama di Tesalonika ( I Tes. 2:3-9). Dia tidak ingin menjadi beban bagi jemaat, sehingga rela bekerja dengan keras. Namun semuanya itu dilakukan supaya orangorang di Tesalonika dapat "hidup sesuai dengan kehendak Allah" (ayat 1112). Bisnis tenda Paulus telah memberikan dukungan bagi dirinya dan rekannya untuk tetap bertahan dalam misi pemberitaan Injil. Hasilnya para penyembah berhala tersebut berbalik kepada Allah bahkan menjadi teladan bagi jemaat-jemaat di wilayah Makedonia , Akhaya dan di semua tempat (1 Tes. 1:2-10). 
Berdasarkan temuan di atas, tampak bahwa kewirausahaan Paulus pada dasarnya adalah social entrepreneurship. Hal ini didasarkan dari karakteristik Paulus dan kewirausahaannya. Paulus adalah seorang social entrepreneur yang inovatif, kreatif dan mampu melihat peluang. Di samping itu dia mandiri namun mampu bekerjasama dengan orang lain bahkan peduli kepada orang lain serta terlibat aktif dalam transformasi sosial di tengah-tengah masyarakat melalui pekerjaannya.

\section{Penerapan Kewirausahaan Paulus Bagi Wirausahawan Kristen Masa Kini}

Pada dasarnya Paulus adalah Social Enterpreneur. Melalui karakteristik kewirausahaannya tersebut, para wirausahawan Kristen masa kini dapat menerapkan di dalam dunia bisnisnya. Adapun penerapannya adalah sebagai berikut: Pertama, wirausahawan Kristen masa kini dapat mulai membangun bisnis yang berorientasi pada Social Enterpreneurship. Sebagai contoh, ketika Bishop Wayan Mastra melihat keterpurukan ekonomi jemaat maka dia berinisiatif untuk mengajak sinode Gereja Kristen Protestan Bali (GKPB) untuk membentuk bisnis yang berorientasi sosial yang dapat mengentaskan warga jemaat GKPB dari kemiskinan (Julianto, 2016). Adapun bentuk usahanya antara lain perhotelan, jasa pernikahan warga negara asing, rumah retret, sekolah perhotelan, usaha mebel, bank perkreditan, dan usaha percetakan (Julianto, 2016). Melalui bentuk-bentuk usaha tersebut, jemaat GKPB 
telah mendapatkan solusi bagi masalah mereka bahkan masyarakat sekitar mendapatkan berkat melalui berbagai pendampingan usaha.

Kedua, wirausahawan Kristen seyogyanya lebih inovatif, kreatif , mampu membaca peluang dengan baik, mandiri serta mampu bekerja sama dengan siapapun. Kemampuan tersebut merupakan proses panjang yang harus terus diasah melalui kompetensi dan kepekaan sosial. Sebagai seorang Social Enterpreneur, wirausahawan Kristen harus mampu melihat masalah di tengah masyarakat sebagai peluang untuk membentuk model bisnis baru bagi pemberdayaan masyarakat di sekitarnya (Sofia, 2017). Adapun hasil yang dicapai bukan sekedar keuntungan materi atau kepuasan pelanggan namun dampak yang jauh lebih besar bagi masyarakat. Ini hanya bisa terjadi melalui keterbukaan dalam menjalin relasi dengan berbagai pihak sebagai modal sosial dalam membentuk Social Enterpreneurship (E. S. Saragih, 2019).

Ketiga, sebagai Social Enterpreneur, wirausahawan Kristen harus menggunakan hasil usahanya untuk kebutuhan orang lain serta terlibat aktif dalam proses transformasi sosial. Bidang-bidang usaha yang dibangun oleh mereka seyogyanya memberikan dampak sosial bagi masyarakat. Social Enterpreneur akan menjadikan kewirausahaannya sebagai metode untuk melakukan transformasi sosial berdasarkan prinsipprinsip kewirausahaan sosial (E. S. Saragih, 2019) 


\section{KESIMPULAN}

Beradasarkan kajian dalam penelitian ini maka penulis menemukan bahwa Paulus adalah seorang Social Enterpreneur. Melalui karakteristik kewirausahaannya, gereja dapat mengembangkan Social Entrepreneurship sebagai salah satu bentuk pelayanan diakonia. Selanjutnya, penulis juga menemukan bahwa para wirausahawan Kristen yang ada di dalam gereja dapat menjadi pelaku Social Entrepreneurship dengan membangun bisnis yang berorientasi kepada pemberdayaan dan transformasi sosial. Hal ini dapat dilakukannya dengan melibatkan pihakpihak lain sebagai modal sosial serta karakteristik dirinya yang inovatif, kreatif, mampu membaca peluang dengan baik, jiwa penolong dan aktif dalam menyelesaikan problematika yang ada di dalam masyarakat.

Melalui penelitian ini, peneliti ingin berkontribusi dalam pengembangan Social Entrepreneurship di dalam gereja sebagai salah satu wujud pelayanan diakonia dengan melibatkan para wirausahawan Kristen. Selain itu, penelitian ini juga dapat menjadi salah satu referensi bagi peneliti lainnya yang ingin menindaklanjuti penelitian ini.

\section{DAFTAR PUSTAKA}

Adi, S. (2020). Kewirausahaan Dan Panggilan Kristen: Sebuah Pendekatan Interpretatif-Dialogis, Sosio-Historis Dan Teologis. Kurios: Jurnal Teologi dan Pendidikan Agama Kristen, 6(1), 18-34. https://doi.org/10.30995/kur.v6i1.123

Al-Kahfi, M. F. (2020). Social Enterprise Berbasis Ekonomi Proteksi. Khazanah: Jurnal Mahasiswa, 11(2), 1-10.

Bikse, V., Rivza, B., \& Riemere, I. (2015). The Social Entrepreneur as a Promoter of Social Advancement. Procedia - Social and Behavioral 
Sciences, 185 , https://doi.org/10.1016/j.sbspro.2015.03.405

$469-478$.

Canestrino, R., Ćwiklicki, M., Magliocca, P., \& Pawełek, B. (2020). Understanding social entrepreneurship: A cultural perspective in business research. Journal of Business Research, 110(January), 132-143. https://doi.org/10.1016/j.jbusres.2020.01.006

Diandra, D., \& Azmy, A. (2020). Understanding Definition of Entrepreneurship. International Journal of Management, Accounting and Economics, 7(5), 235-242.

Filion, L. J. (2011). Defining the Entrepreneurship. In Word Encyclopedia of Enterpreneurship. Edward Elgar Publishing.

Julianto, S. (2016). Kewirausahaan Jemaat: Sebuah Alternatif Berteologi. WASKITA: Jurnal Studi Agama dan Masyarakat, 3(1), 151-183.

Kickul, J., Terjesen, S., Bacq, S., \& Griffiths, M. (2012). Social Business Education: An Interview With Nobel Laureate Muhammad Yunus. Academy of Management Learning \& Education, 11(3), 453-462.

Kusni, M. (2020). Jiwa Entrepreneurship Pemimpin dalam Penatalayanan Gereja. Jurnal Teologi Kependetaan, 10(2), 160-175.

Leeman, R. W. (2017). Rhetorical Criticism. In K. B. Jensen \& R. T. Craig (Ed.), The International Encyclopedia of Communication Research Methods (I, Nomor I, hal. 1-11). John Wiley and Sons Ltd. https://doi.org/10.1002/9781118901731.iecrm0219

Lubberink, R., Blok, V., van Ophem, J., \& Omta, O. (2019). Responsible innovation by social entrepreneurs: an exploratory study of values integration in innovations. Journal of Responsible Innovation, 6(2), 179-210. https://doi.org/10.1080/23299460.2019.1572374

Manyaka, S. J. (2015). Social entrepreneurship: A solution for transforming the disadvantaged community of Nellmapius. HTS Teologiese Studies / Theological Studies, 71(3), 1-7. https://doi.org/10.4102/hts.v71i3.2821

Margahana, H. (2020). Urgensi Pendidikan Entrepreneurship Dalam Membentuk Karakter Entrepreneur. Jurnal IImiah Ekonomi dan Bisnis, 17(2), 176-183. https://doi.org/10.31849/jieb.v17i2.4096

Mursalim, S. W. M. dan T. K., \& Kurniati, T. (2020). Sociopreneurship Sebagai Upaya Pemberdayaan di Kota Tasikmalaya. Prosiding Konfrensi Nasional Ilmu Administrasi, 182-186.

Palabirin, B., \& Ronda, D. (2010). Pandangan Alkitab Tentang Praktik Bisnis di Kalangan Hamba Tuhan Penuh Waktu. Jurnal Jaffray, 8(2), 35. https://doi.org/10.25278/jj71.v8i2.45

Pasande, P., \& Tari, E. (2019). Peran Gereja Dalam Pengembangan 
Program Kewirausahaan Di Era Digital. Visio Dei: Jurnal Teologi Kristen, 38-58. https://doi.org/10.35909/visiodei.v1i1.6

Saragih, E. S. (2019). Fungsi Gereja Sebagai Entrepreneurship Sosial dalam Masyarakat Majemuk. Kurios: Jurnal Teologi dan Pendidikan Agama Kristen, 5(1), 12-23. https://doi.org/10.30995/kur.v5i1.89

Saragih, R., \& Elisabeth, D. M. (2020). Kewirausahaan Sosial Dibalik Pandemi Penelusuran Profil dan Strategi Bertahan. Jurnal Manajemen, 6(1), 47-56.

Setiawan, D. E., \& Yulianingsih, D. (2019). Signifikansi Salib Bagi Kehidupan Manusia dalam Teologi Paulus. FIDEl: Jurnal Teologi Sistematika dan Praktika, 2(2), 227-246. https://doi.org/10.34081/fidei.v2i2.73

Silalahi, J. N. (2019). Paulus Sang Entrepreneur: Pembuat Tenda Sebagai Jembatan Penginjilan. Visio Dei: Jurnal Teologi Kristen, 1-18. https://doi.org/10.35909/visiodei.v1i1.9

Sofia, I. P. (2017). Konstruksi Model Kewirausahaan Sosial (Social Entrepreneurship) Sebagai Gagasan Inovasi Sosial Bagi Pembangunan Perekonomian. Widyakala Journal, 2(1), 2. https://doi.org/10.36262/widyakala.v2i1.7

Szesnat, H. (1993). What Did The Skenopoios Paul Produce? Neotestamentica: Journal of the New Testament Society of South Africa, 27(2), 1-3.

Tafonao, T. (2020). Pendidikan Kewirausahaan Bagi Warga Gereja Di Era Digital. Visio Dei: Jurnal Teologi Kristen, 2(1), 127-146. https://doi.org/10.35909/visiodei.v2i1.81

Trygu. (2020). Studi Literatur Problem Based Learning Untuk Motivasi Bagi Siswa Dalam Belajar Matematika (Guepedia/La (ed.); I). Guepedia Group.

Utomo, H. (2014). Menumbuhkan Minat Kewirausahaan Sosial. Jurnal Ilmiah Among Makarti, 7(14), 1-16. https://doi.org/10.52353/ama.v7i2.99

Wibowo, H., \& Nulhaqim, S. A. (2015). Kewirausahaan Sosial (Merevolusi Pola Pikir Menginisiasi Mitra Pembangunan). Unpad Press.

Yusuf, A. M. (2019). Metode Penelitian Kuantitatif, Kualitatif \& Penelitian Gabungan (5 ed.). Prenadamedia Group.

Zamzami, A. (2019). Pengembangan Desa Industri Dalam Mengembangkan Produk Unggulan. Jurnal Pembelajaran Pemberdayaan Masyarakat (JP2M), 1(1), 42. https://doi.org/10.33474/jp2m.v1i1.5007 